Agr. Biol. Chem., 40 (11), 2237 2243, 1976

\title{
A Thermosensitive Mutant of Bacillus subtilis Deficient in Uracil and Cell Division
}

\author{
Kazuo Nagai, Hideaki Some and Gakuzo Tamura \\ Department of Agricultural Chemistry, University of Tokyo \\ Received June 28, 1976
}

\begin{abstract}
Thermonsenstivie division mutants were derived from Bacillus subtilis Marburg 168 thy $\operatorname{trp}_{2}$ by means of membrane filtration after nitrosoguanidine mutagenesis. Among them, ts 42 requiring uracil for normal growth at $48^{\circ} \mathrm{C}$ was investigated.

In the absence of uracil, the mutant cells grew normally at $37^{\circ} \mathrm{C}$ and stopped dividing after temperature shift to $48^{\circ} \mathrm{C}$ resulting in filaments of two to four times length of normal rods. The total cell number after temperature shift from 37 to $48^{\circ} \mathrm{C}$, increased two to three fold in $90 \mathrm{~min}$ and remained constant thereafter. The viable count after the temperature shift to $48^{\circ} \mathrm{C}$, increased 1.5 to 2 fold in initial $60 \mathrm{~min}$ and then decreased exponentially. A rapid restoration of colony forming ability was shown when the mutant cells were shifted back to the permissive temperature after 120 to $180 \mathrm{~min}$ of incubation at $48^{\circ} \mathrm{C}$ or when uracil was introduced to the culture at $48^{\circ} \mathrm{C}$. This recovery of viability was partly observed even in the presence of chloramphenicol. The synthesis of RNA of this mutant was shown to decline $20 \mathrm{~min}$ after the temperature shift to $48^{\circ} \mathrm{C}$ whereas the syntheses of DNA and protein proceeded for more than $80 \mathrm{~min}$ at that temperature.

No newly isolated uracil requiring mutants formed filaments in the medium lacking uracil or showed growth pattern like ts 42 .
\end{abstract}

The process of cell division involves several steps such as chromosome replication, nuclear segregation, septation and physical separation of daughter cells. ${ }^{1,2)}$ A number of thermosensitive mutants of bacteria including Bacillus subtilis ${ }^{3 \sim 10)}$ defective in individual step of cell division have been isolated. However, it is hardly known what mechanism or material directly regulates the cellular division or septum formation except that some autolytic enzyme is shown to participate in the final step of cell separation. ${ }^{4}$

In the course of our screening for thermosensitive mutants of Bacillus subtilis deficient in cell division, a uracil requiring strain, ts42, has been isolated. This mutant grows normally at the permissive temperature and forms filaments when shifted to the nonpermissive temperature in the absence of uracil. The growth pattern and morphological observation significantly differentiate this mutant from other uracil requiring strains. Therefore, it has been suggested that the mutant is defective in some steps of cell division process.
The isolation and physiological characterization of this mutant are presented in this paper.

\section{MATERIALS AND METHODS}

Media. The liquid culture was grown with aeration in MW (modified Woese's) medium ${ }^{11)}$ containing glucose, $9 \mathrm{~g}$; $\mathrm{Na}$ L-glutamate, $3 \mathrm{~g}$; L-asparagine, $0.3 \mathrm{~g}$; L-alanine, $100 \mathrm{mg}$; L-arginine $\cdot \mathrm{HCl}, 100 \mathrm{mg}$; casamino acids (Difco), $0.5 \mathrm{~g} ; \mathrm{NH}_{4} \mathrm{Cl}, 0.5 \mathrm{~g} ; \mathrm{KCl}, 70 \mathrm{mg} ; \mathrm{Na}_{2} \mathrm{SO}_{4}$, $120 \mathrm{mg} ; \mathrm{MgCl}_{2} \cdot 6 \mathrm{H}_{2} \mathrm{O}, 0.5 \mathrm{~g}$; Ca acetate, $20 \mathrm{mg} ; \mathrm{MnCl}_{2}$. $4 \mathrm{H}_{2} \mathrm{O}, 5 \mathrm{mg}$; $\mathrm{NaH}_{2} \mathrm{PO}_{4} \cdot 2 \mathrm{H}_{2} \mathrm{O}, 156 \mathrm{mg}$; L-tryptophan, $30 \mathrm{mg}$; thymine, $10 \mathrm{mg}$; and Tris (hydroxymethyl) aminomethane, $3 \mathrm{~g} \mathrm{(pH} \mathrm{7.2)} \mathrm{per} \mathrm{liter} \mathrm{of} \mathrm{distilled} \mathrm{water.}$ The cells were allowed to form colony on NBT medium $^{12}$ (cousisted of $10 \mathrm{~g}$ polypeptone, $7 \mathrm{~g}$ meat extract, $3 \mathrm{~g} \mathrm{NaCl}$ and $10 \mathrm{mg}$ thymine per liter of distilled water) solidified with $1.3 \%$ agar.

Isolation of mutants. A thermosensitive mutant requiring uracil, ts 42 , was derived from Bacillus subtilis Marburg 168 thy trp. Following the procedure deviced for the isolation of division mutants of Escherichia coli, ${ }^{19)}$ an exponentially growing culture of the parent strain in MW medium was washed by membrane filtration, suspended in TM buffer containing $100 \mu \mathrm{g} / \mathrm{ml}$ of $\mathrm{N}$-methyl-N'-nitro-N-nitrosoguanidine (NTG) and incubated at $37^{\circ} \mathrm{C}$ for $30 \mathrm{~min}$. TM buffer contained 
$6.057 \mathrm{~g}$ of tris (hydroxymethyl)-aminomethane, $5.804 \mathrm{~g}$ of maleic acid, $0.1 \mathrm{~g}$ of $\mathrm{MgSO}_{4} \cdot 7 \mathrm{H}_{2} \mathrm{O}, 1 \mathrm{~g}$ of $\left(\mathrm{NH}_{4}\right)_{2} \mathrm{SO}_{4}$, $0.5 \mathrm{~g}$ of sodium citrate per liter of distilled water and $\mathrm{pH}$ was adjusted to $6.0 .^{14)}$ The cells were washed by filtration and suspended in fresh MW medium. The culture was filtered through a membrane filter, $8 \mu \mathrm{m}$ pore size, after $120 \mathrm{~min}$ of cultivation at $48^{\circ} \mathrm{C}$. The elongated cells retained on the filter were examined as to the colony forming ability at $37^{\circ} \mathrm{C}$ on $\mathrm{NBT}$-agar plates. The colonies on the NBT-agar plate were replicated on a couple of $\mathrm{MW}$-agar plates. The mutant strain was isolated from those which could form colony at $37^{\circ} \mathrm{C}$ but not at $48^{\circ} \mathrm{C}$.

The cell morphology was examined by a phasecontrast microscope after cultivation at 37 or $48^{\circ} \mathrm{C}$ in MW medium.

The mutants deficient in uracil were prepared by the following method. The cells of Bacillus subtilis Marburg 168 thy tap 2 , treated with NTG as described above, were suspended in MW medium supplemented with $10 \mu \mathrm{g} / \mathrm{ml}$ of uracil and incubated for $120 \mathrm{~min}$ at $37^{\circ} \mathrm{C}$. The culture was washed and resuspended in MW medium. After cultivation for $90 \mathrm{~min}$ at $37^{\circ} \mathrm{C}$, the cells were washed, suspended in MW medium lacking thymine and incubated for $120 \mathrm{~min}$ at $37^{\circ} \mathrm{C}$. The cells were spread on NBT-agar plates after appropriate dilution with phosphate buffer $(0.067 \mathrm{M}, \mathrm{pH} 6.8)$. The uracil requirement of the mutants were assayed by colony forming ability after replica printing on a couple of plates with or without uracil. Six uracil auxotroph mutants were isolated by this procedure.

Total and viable count of cells. Total number and volume of cells were examined by a Coulter Counter Model $\mathrm{Zb}$, Coulter Electrics Inc., after suitable dilution of culture with filtered saline. Viable counts were assayed by colony forming ability on NBT-agar plate after $20 \mathrm{hr}$ of incubation at $37^{\circ} \mathrm{C}$.

Macromolecular syntheses. The syntheses of DNA and RNA were assayed by the incorporation of adenine${ }^{2}{ }^{14} \mathrm{C}$ (Daiichi Pure Chemicals Co., Ltd.) after fractionation by the method of Schmidt and Thannhauser ${ }^{15)}$ as described previously. ${ }^{12)}$ Protein content was measured following the procedure of Lowry et al. ${ }^{16)}$

\section{RESULTS}

\section{Isolation of thermosensitive mutants deficient in cell division}

The parent strain treated with NTG was filtered through a membrane filter, $8 \mu \mathrm{m}$ pore size, after $120 \mathrm{~min}$ of incubation at $48^{\circ} \mathrm{C}$ as described in the method. Among about 84,000 viable cells retained on the filter, 168
Table I. Grouping of the Thermosensitive Mutants of Bacillus subtilis

The strains in group II form filament at the logarithmic phase but divide in the stationary phase of growth at $48^{\circ} \mathrm{C}$.

\begin{tabular}{rllc}
\hline Group & \multicolumn{2}{c}{ Morphology at } & $\begin{array}{c}\text { Number of } \\
\text { Mutants }\end{array}$ \\
\hline I & Normal & Filament & 18 \\
II & Normal & Filament/Normal & 9 \\
III & Filament & Filament & 23 \\
IV & Normal & Sphere and/or & 10 \\
& & Tadpole & 108 \\
V & Normal & Normal & 10 \\
\hline
\end{tabular}

strains were found to be defective in colony forming ability on $\mathrm{MW}$-agar plate at $48^{\circ} \mathrm{C}$. Therefore, the percentage of thermosensitive mutants was about 0.2 of the filtered cells. These temperature sensitive mutants were divided into five groups in the respect of cell morphology at 37 and $48^{\circ} \mathrm{C}$ in $\mathrm{MW}$ medium. As shown in Table I, 60 mutants formed filamentous cells at $48^{\circ} \mathrm{C}$ only or at both 37 and $48^{\circ} \mathrm{C}$ and those in group I were suggested to be temperature sensitive division mutants.

Among the mutants in group $\mathrm{I}, \mathrm{ts} 42$ formed colony on an NBT-agar plate at $48^{\circ} \mathrm{C}$. Therefore, some factor contained in NBT was suggested to support cell viability of this mutant at that temperature. The mutant strain was revealed to be uracil deficient at $48^{\circ} \mathrm{C}$ after the auxanography test using MW medium supplemented with mixture of amino acids, vitamines or nucleobases.

\section{Growth of ts 42 at 37 and $48^{\circ} \mathrm{C}$}

The increase of absorbance at $550 \mathrm{~nm}$ and the number of total cells at 37 and $48^{\circ} \mathrm{C}$ are shown in Fig. 1. An exponentially growing culture of ts 42 at $37^{\circ} \mathrm{C}$ was divided into two parts at an absorbance of 0.2 . One part was cultivated at $37^{\circ} \mathrm{C}$ and the other was shifted to $48^{\circ} \mathrm{C}$. After the shift to $48^{\circ} \mathrm{C}$, the increase of absorbance was a little more rapid for initial $30 \mathrm{~min}$ but slower thereafter than it was at $37^{\circ} \mathrm{C}$ and undetectable after $4 \mathrm{hr}$. The relative increase of absorbance was about three during this period. The number of cells increased exponentially at the permissive temperature. However, at $48^{\circ} \mathrm{C}$, the total cell 


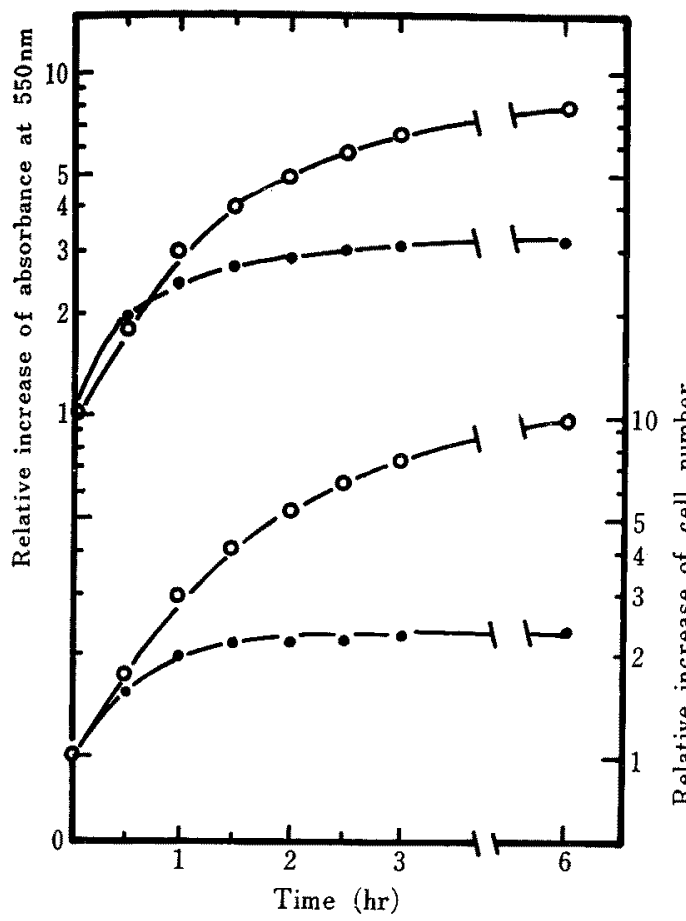

FIG. 1. Relative Increase of Absorbance and Total Cell Number of ts 42 at 37 and $48^{\circ} \mathrm{C}$.

Exponentially growing culture of ts 42 at $37^{\circ} \mathrm{C}$ was divided into two fractions at $\mathrm{A}_{550}: 0.2$. One was incubated at $37^{\circ} \mathrm{C}(\mathrm{O})$ and the other was shifted to $48^{\circ} \mathrm{C}$ ). count reached about twice of that before the temperature shift within 120 min and remained constant thereafter. The cells proliferated exponentially at $48^{\circ} \mathrm{C}$ provided that uracil was introduced to the culture in MW medium. The increase of viable cell number was exponential as in the case of total count at $37^{\circ} \mathrm{C}$. However, at $48^{\circ} \mathrm{C}$, the viable cells doubled during initial $60 \mathrm{~min}$ and decrease exponentially $90 \mathrm{~min}$ after the temperature shift. When the culture was shifted back to $37^{\circ} \mathrm{C}$ after 120 to $180 \mathrm{~min}$ of incubation at $48^{\circ} \mathrm{C}$, very rapid restoration of cell viability was observed after $30 \mathrm{~min}$ of lag. The similar restoration but with a shorter lag period was shown when uracil was added to the culture at $48^{\circ} \mathrm{C}$. The results are presented in Fig. $2 \mathrm{~A}$ and B.

Cell volume and morphology at 37 and $48^{\circ} \mathrm{C}$

The distribution of cell volume among the population was examined periodically at 37 and $48^{\circ} \mathrm{C}$ (Fig. 3). There was almost no change in distribution during the incubation period at $37^{\circ} \mathrm{C}$. The similar pattern of distribution was also observed after $60 \mathrm{~min}$ of incubation at $48^{\circ} \mathrm{C}$ in which period the cell

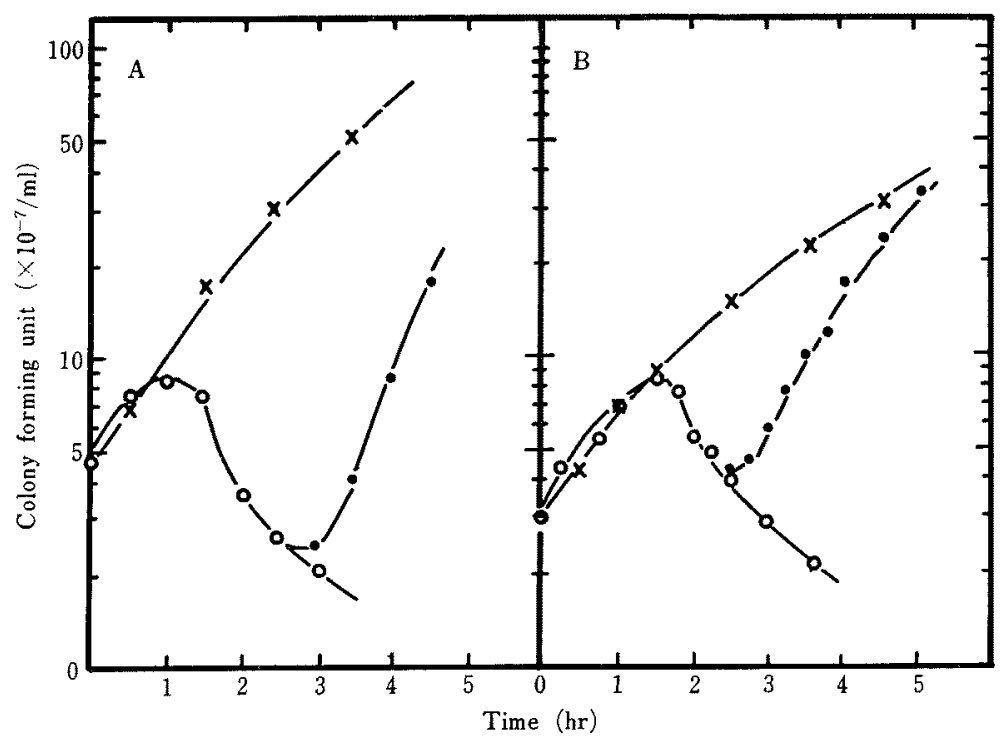

FIG. 2. Restoration of Colony Forming Ability of ts 42 .

The culture of ts 42 at $37^{\circ} \mathrm{C}$ was divided into two parts at $\mathrm{A}_{\overline{5} 50}: 0.2$. One was incubated at $37^{\circ} \mathrm{C}(\times)$ and the other was shifted to $48^{\circ} \mathrm{C}(\mathrm{O})$. After $2.5 \mathrm{hr}$ at $48^{\circ} \mathrm{C}$, a part of the culture was shifted back to $37^{\circ} \mathrm{C}(0$ in $\mathrm{A})$ or $10 \mu \mathrm{g} / \mathrm{ml}$ of uracil was introduced to the culture at $48^{\circ} \mathrm{C}(\mathbf{i n} \mathrm{B})$. 


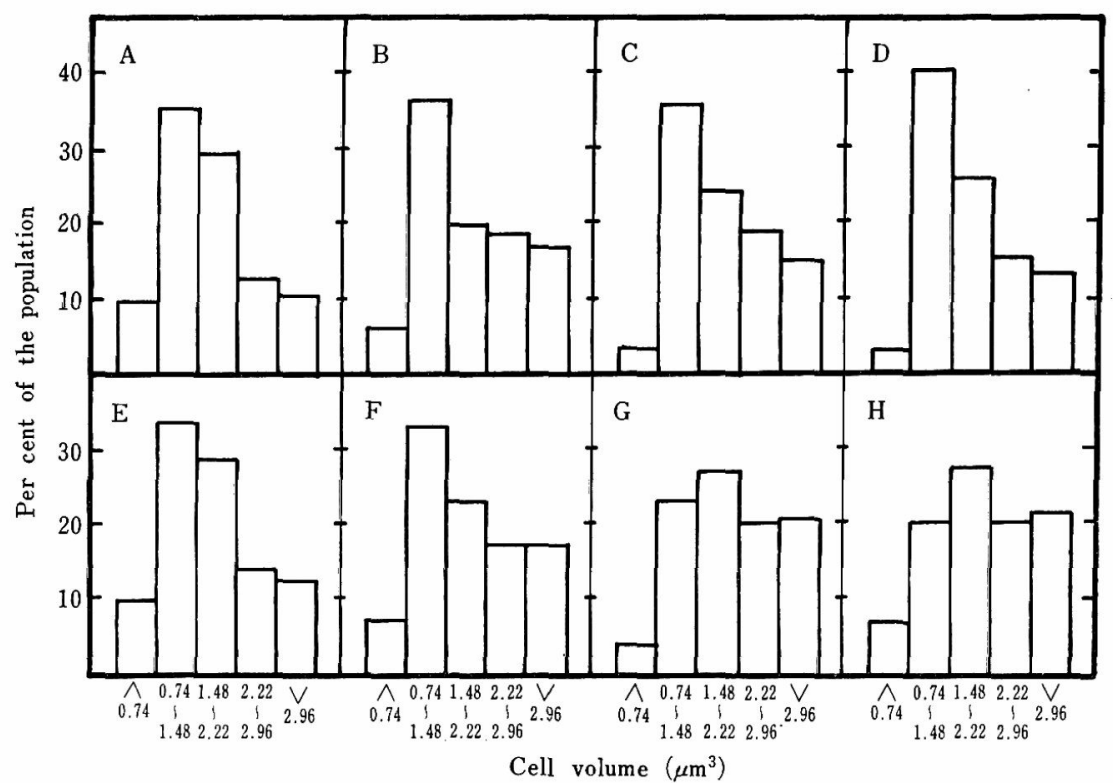

Fig. 3. Distribution of Cell Volume of ts 42 Cultured at 37 and $48^{\circ} \mathrm{C}$.

An exponentially growing culture of ts 42 at $37^{\circ} \mathrm{C}$ was divided into two parts at $\mathrm{A}_{550}: 0.2$. One was incubated at $37^{\circ} \mathrm{C}(\mathrm{A}-\mathrm{D})$ and the other was shifted to $48^{\circ} \mathrm{C}(\mathrm{E}-\mathrm{H})$. The distribution of cell volume was examined by a Coulter Counter $0(\mathrm{~A}, \mathrm{E}), 1(\mathrm{~B}, \mathrm{~F}), 2(\mathrm{C}, \mathrm{G})$ and $3(\mathrm{D}, \mathrm{H}) \mathrm{hr}$ after incubation. The cell volume was calculated from the value of thresholds for half count of standard particles.
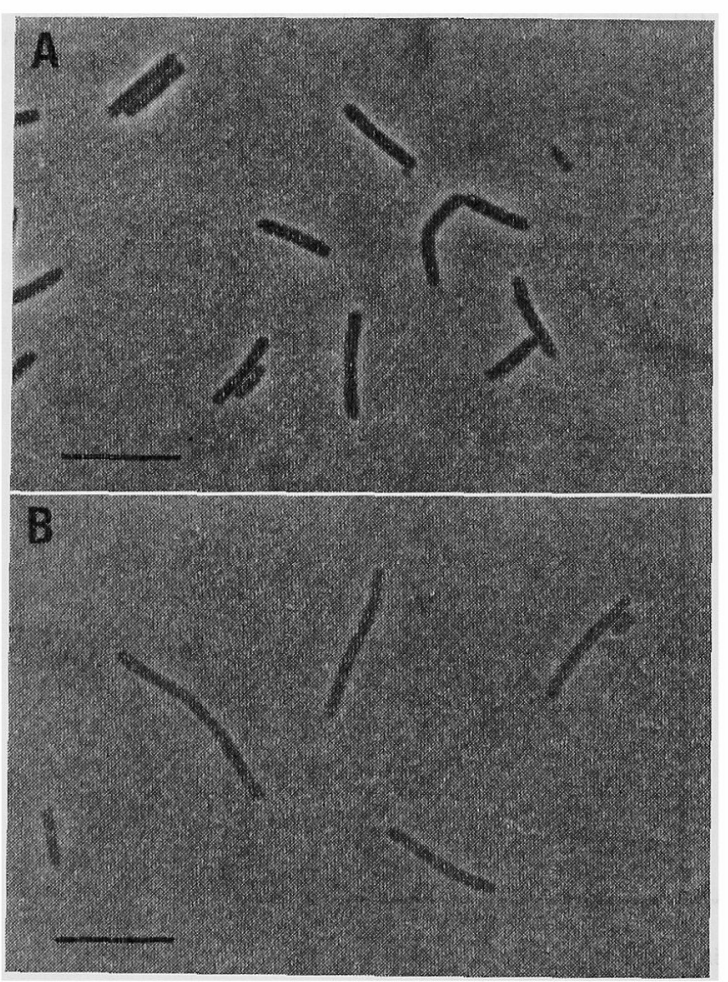

Plate 1. Morphological Observation of ts42 Cells in MW Medium.

A: exponentially growing cells at $37^{\circ} \mathrm{C}$.

$\mathrm{B}$ : after $3 \mathrm{hr}$ of incubation at $48^{\circ} \mathrm{C}$. Marker represents $10 \mu \mathrm{m}$. number doubled. However, after $3 \mathrm{hr}$ at $48^{\circ} \mathrm{C}$, the population of the cells with larger volume increased in comparison with those incubated at $37^{\circ} \mathrm{C}$. The thickness of the cells was identical at 37 and $48^{\circ} \mathrm{C}$ as observed microscopically. Therefore, this increase of volume corresponded to the elongation of the cells. The typical figures of the cells at 37 and $48^{\circ} \mathrm{C}$ are presented in Plate $1 \mathrm{~A}$ and $\mathrm{B}$. The cells obtained from the culture at $48^{\circ} \mathrm{C}$ after $3 \mathrm{hr}$ of incubation showed the length of two to four times of the normal rods at $37^{\circ} \mathrm{C}$.

Effect of chloramphenicol (CAP) on restoration of viability of $t s 42$

It was examined whether new protein synthesis is required to recover colony forming ability when ts 42 was shifted back from 48 to $37^{\circ} \mathrm{C}$ (Fig. 4A) or when uracil was introduced to the culture at $48^{\circ} \mathrm{C}$ (Fig. 4B). After $150 \mathrm{~min}$ of incubation at $48^{\circ} \mathrm{C}, 10 \mu \mathrm{g} / \mathrm{ml}$ of $\mathrm{CAP}$ was added to the culture. In the case when the culture was incubated at $48^{\circ} \mathrm{C}$, the cell viability remained constant in the presence of CAP whereas it reduced exponentially in the absence of CAP. However, a part of the cell popula- 


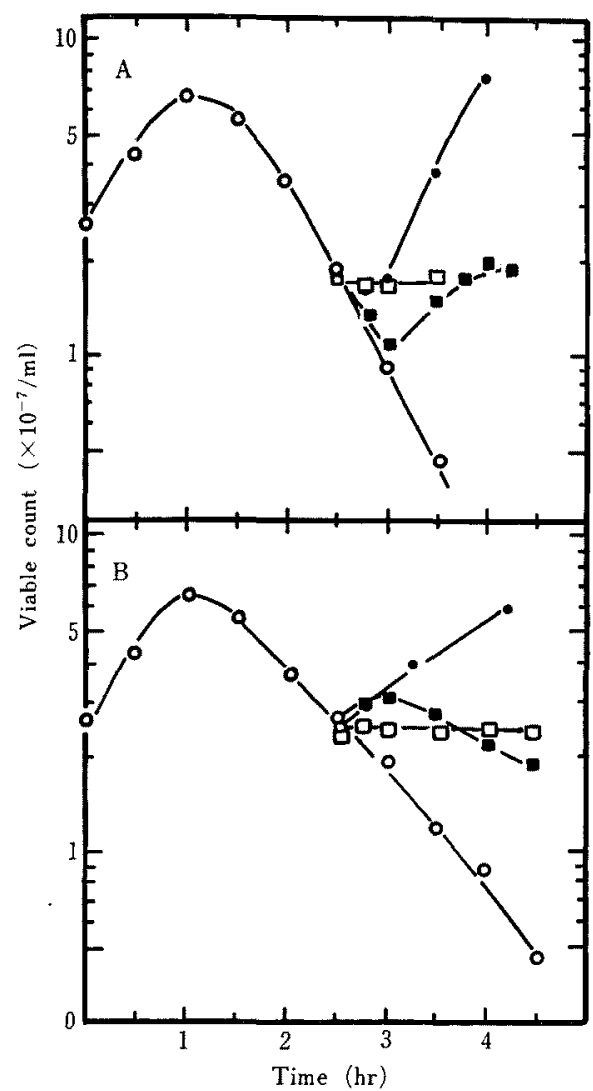

FIG. 4. Effect of CAP on Restoration of Colony Forming Ability of ts 42 .

After $2.5 \mathrm{hr}$ of incubation at $48^{\circ} \mathrm{C}$, a part of the culture was shifted back to $37^{\circ} \mathrm{C}$ (A) or uracil $(10 \mu \mathrm{g} / \mathrm{ml})$ was introduced to a part of the culture at $48^{\circ} \mathrm{C}(\mathrm{B})$. A: The cells were retained at $48^{\circ} \mathrm{C}(\mathrm{O}, \square)$ or shifted back to $37^{\circ} \mathrm{C}(\boldsymbol{0}, \mathbf{0})$ at $2.5 \mathrm{hr} . \quad \mathrm{CAP}(10 \mu \mathrm{g} / \mathrm{ml})$ was added at $2.5 \mathrm{hr}(\square, \square)$. B: The cells were retained at $48^{\circ} \mathrm{C}$ with $(\square, 4)$ or without $(O, \square)$ the addition of uracil $(10 \mu \mathrm{g} / \mathrm{ml})$ at $2.5 \mathrm{hr}$. CAP was introduced to the culture at 2.5 hr $(\square, \mathbf{0})$.

tion could restore colony forming ability in the presence of CAP when the cell suspension was shifted back to $37^{\circ} \mathrm{C}$ or uracil was introduced to the culture at $48^{\circ} \mathrm{C}$. Analogous to the case without $\mathrm{CAP}$, there was a lag period before the cell restored viability when the culture was shifted back to $37^{\circ} \mathrm{C}$ in the presence of CAP whereas almost no lag was observed in the case of uracil addition at $48^{\circ} \mathrm{C}$. The viability of the cells decreased again after restoration was observed in the presence of uracil and CAP at $48^{\circ} \mathrm{C}$.
Macromolecular synthesis of ts 42 at 37 and $48^{\circ} \mathrm{C}$

The effect of temperature shift was examined on macromolecular synthesis of the mutant ts42 (Fig. 5). The net increase of protein and the incorporation of adenine $-{ }^{14} \mathrm{C}$ into DNA fraction were more rapid at least for 80 $\min$ at $48^{\circ} \mathrm{C}$ than at $37^{\circ} \mathrm{C}$. However, the incorporation of adenine $-{ }^{14} \mathrm{C}$ into RNA fraction was significantly slowed down 20 min after the temperature shift. Thus it was revealed that RNA synthesis was selectively suppressed at an early stage after the temperature shift. This result coincided with the uracil requirement of this mutant at the nonpermissive temperature.
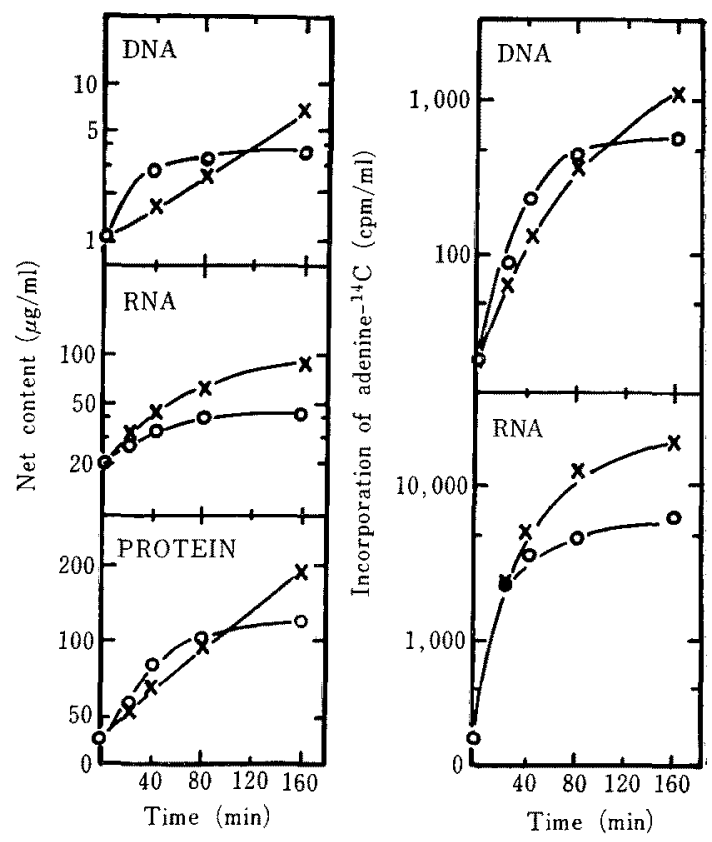

FIG. 5. Macromolecular Synthesis of ts42 at 37 and $48^{\circ} \mathrm{C}$.

Exponentially growing cells of ts 42 at $37^{\circ} \mathrm{C}$ was divided into two parts at $\mathrm{A}_{650}: 0.2$. One was incubated at $37^{\circ} \mathrm{C}(x)$ and the other was shifted to $48^{\circ} \mathrm{C}(\mathrm{O})$. Net increase of RNA and DNA or incorporation of adenine $-{ }^{14} \mathrm{C}$ into RNA and DNA was calculated after fractionation by the method of Schmidt and Thannhauser. The content of protein was estimated following Lowry et al.

\section{Comparison of $t \$ 42$ with other uracil requiring mutants}

On uracil deficient mutants of Bacillus subtilis, uracil-less death ${ }^{17\}}$ but no morphological 
observation or rapid recovery of colony forming ability like ts 42 has been reported.

It has been shown by Maaløe and Hanawalt $^{18)}$ that the mutants which require both uracil and thymine escape thymine-less death when thymine was deprived from the medium several hours after uracil deprivation. The parent strain of ts42, Bacillus subtilis Marburg 168 thy trp , was auxotroph for thymine. Therefore, uracil requiring mutants derived from the parent strain were expected to survive if the cell suspension was cultured in the medium lacking both uracil and thymine. Following the procedure described in the method, six mutants requiring uracil were isolated. The growth, viability, restoration of viability by addition of uracil and morphological observation of these mutants were compared with those of ts42.

As shown in Fig. 6, one of the strains, U-5 showed similar reduction of viability following uracil deprivation but failed to show rapid restoration of colony forming ability when uracil was introduced to the culture. Two of the

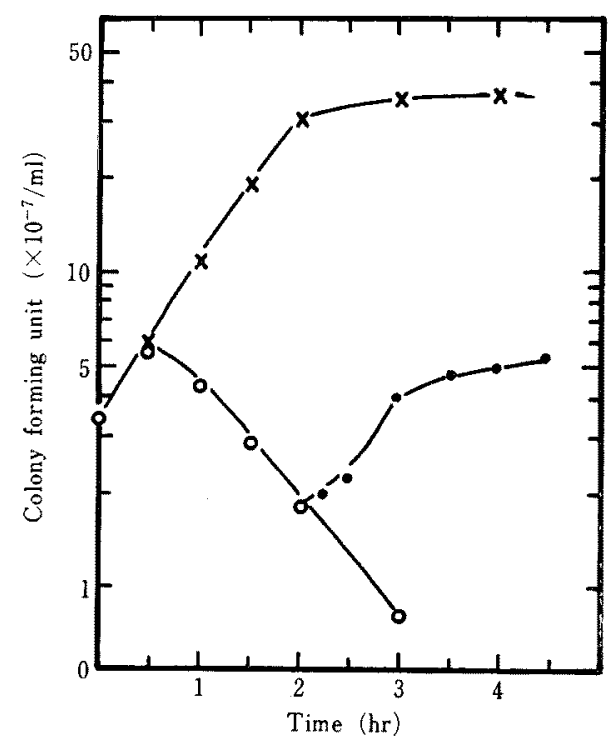

Fig. 6. Effect of Uracil on Restoration of Colony Forming Ability of $\mathrm{U}-5$.

A part of the exponentially growing culture of U-5 was divided into two fractions. One was incubated at $37^{\circ} \mathrm{C}(x)$ and the other was shifted to the medium without uracil and incubated at $48^{\circ} \mathrm{C}(0)$. After 120 $\min$ at $48^{\circ} \mathrm{C}$, uracil $(10 \mu \mathrm{g} / \mathrm{ml})$ was introduced to a part of the culture and shifted back to $37^{\circ} \mathrm{C}(\boldsymbol{\bullet})$. mutants $U-3$ and $U-4$, formed cells of tadpole shape in the absence of uracil. There was no mutants which elongate in the medium lacking uracil. Therefore, no mutants was found to be analogous to the present one, ts 42 .

\section{DISCUSSION}

In a previous paper, ${ }^{13)}$ thermosensitive mutants of Escherichia coli deficient in cell division were reported to be isolated following membrane filtration after NTG mutagenesis. The percentage of the thermosensitive strains was 0.1 of the filtered cells. In the present result on Bacillus subtilis, it was 0.2 per cent. However, about a half of these temperature sensitive strains was found to be normal in shape even at nonpermissive temperature. This may be ascribed to the fact that $B$. subtilis cells are easy to form filaments or rosary cells at logarithmic phase of growth which result in cells longer than the pore size $(8 \mu \mathrm{m})$ of the membrane filter. In addition to this, a part of the isolated strains elongated both at permissive and nonpermissive temperatures. As a result, three of the eighteen mutants that belonged to group I in Table I were concluded to be thermosensitive in the process of cell division. One of them, ts 42 , was examined intensively in the present work.

The mutant ts 42 was revealed to be uracil auxotroph at nonpermissive temperature following auxanography test. The colony forming ability of ts 42 , when shifted from 37 to $48^{\circ} \mathrm{C}$, decreased exponentially after about $90 \mathrm{~min}$, while the cell gradually elongated and became two to four times as long as the normal rod after $3 \mathrm{hr}$ of incubation at $48^{\circ} \mathrm{C}$. However, when the culture was shifted back to $37^{\circ} \mathrm{C}$, the cells rapidly restored viability after $30 \mathrm{~min}$ of lag period. The synthesis of RNA, assayed by the incorporation of adenine- ${ }^{14} \mathrm{C}$, slowed down suddenly after $20 \mathrm{~min}$ of incubation at $48^{\circ} \mathrm{C}$ whereas DNA and protein continuously increased for more than $80 \mathrm{~min}$ at that temperature. Therefore, uracil, residually present in the cell after 20 min at $48^{\circ} \mathrm{C}$, might be mainly incorporated 
into mRNA and utilized for protein synthesis in this mutant. Another pathway requiring uracil including cell wall, septum and envelope formation could be defective in this condition. This might be the cause that the mutant ts 42 formed elongated cells without septa and concomitantly lost viability at $48^{\circ} \mathrm{C}$. Similar deficiency of uracil might lead other mutants U-3 and U-4 to form cells of tadpole shape.

The true mechanism how uracil deficiency concerns these pleiotropic effects remains to be elucidated but the unbalance between the two pathways will be most plausible as the cause of the present results. This concept was also supported by the fact that ts 42 retained viability at $48^{\circ} \mathrm{C}$ when salts such as potassium chloride and sodium succinate were added to the medium. ${ }^{19}$ These phenotypic observations suggest that this strain is a new type of division mutant. Further study of ts 42 will reveal new aspect on the role of uracil or its derivatives in the cell division process.

Acknowledgment. This work was supported by a grant from the Ministry of Education, Japan.

\section{REFERENCES}

1) C. E. Helmstetter, Ann. Rev. Microbiol., 23, 223 (1969).
2) M. Slater and M. Schaechter, Bacteriol. Rev., 38, 199 (1974).

3) N. H. Mendelson and J. D. Gross, J. Bacteriol., 94, 1603 (1967).

4) D. P. Fan and M. M. Beckman, ibid., 105, 629 (1971),

5) D. V. Alstyne and M. I. Simon, ibid., 108, 1366 (1971).

6) N. H. Mendelson, ibid., 111, 156 (1972).

7) N. H. Mendelson and R. M. Cole, ibid., 112, 994 (1972).

8) X. O. Breakefield and O. E. Landman, ibid., 113, 985 (1973).

9) J. N. Reeve, N. H. Mendelson, S. I. Coyne, L. L. Hallock and R. M. Cole, ibid., 114, 860 (1973).

10) M. G. Sargent, ibid., 123, 1218 (1975).

11) J. Nukushina and Y. Ikeda, Genetics, 63, 63 (1969).

12) K. Nagai and G. Tamura, J. Bacteriol., 112, 959 (1972).

13) K. Nagai, H. Kaneko and G. Tamura, Biochem. Biophys. Res. Commun., 42, 669 (1971).

14) E. A. Adelberg, M. Mandel and G. C. Ching Chen ibid., 18, 788 (1965).

15) G. Schmidt and S. J. Thannhauser, J. Biol. Chem., 161, 83 (1945).

16) O. H. Lowry, N. J. Rosebrough, A. L. Farr and R. L. Ranall, ibid., 193, 265 (1951).

17) W. B. Pritikin and W. R. Roming, J. Bacteriol, 92, 291 (1966).

18) O. Maaløe and P. C. Hanawalt, J. Mol. Biol., 3, 144 (1961).

19) N. Miyazaki, K. Nagai and G. Tamura, in preparation. 